\title{
Design, synthesis and characterization of $1 H$-pyridin-4-yl-3, 5-disubstituted indazoles and their anti-inflammatory and analgesic activity
}

\author{
ARAVA VEERA REDDY ${ }^{\mathrm{a}, *}$, SURENDRAREDDY GOGIREDDY ${ }^{\mathrm{a}}, \mathrm{P}^{\mathrm{K}}$ DUBEY ${ }^{\mathrm{b}}$, \\ MADHAVA REDDY $\mathrm{B}^{\mathrm{c}}$ and VEERESH $\mathrm{B}^{\mathrm{c}}$ \\ ${ }^{a}$ R\&D Centre, Suven Life Sciences Ltd., Plot No\#18, Phase-III, Jeedimetla, Hyderabad 500055, India \\ ${ }^{b}$ Department of Chemistry, J.N.T. University, Hyderabad 500072, India \\ ${ }^{\mathrm{c}}$ Department of Pharmacology \& Toxicology, G. Pulla Reddy College of Pharmacy, Mehdipatnam, \\ Hyderabad 500028, India \\ e-mail: reddyvenis@rediffmail.com
}

MS received 1 April 2014; revised 8 July 2014; accepted 27 July 2014

\begin{abstract}
A new series of $1 \mathrm{H}$-pyridin-4-yl-indazole-3-carboxylic acid and its derivatives were synthesized from indazole-3-carboxylic acid methyl ester and 2-cyano-4-chloropyridine. All the new compounds have been characterized by spectral data and subsequently evaluated for their anti-inflammatory and analgesic activity.
\end{abstract}

Keywords. $1 H$-pyridin-4-yl-3,5-disubstituted indazoles; anti-inflammatory and analgesic activity.

\section{Introduction}

Among the heterocyclic compounds, indazole moiety has been of great interest to the research community due to its wide variety of biological properties such as anti-cancer, ${ }^{1}$ anti-hypertensive, ${ }^{2}$ anti-viral ${ }^{3}$ and anti-angiogenic agents. ${ }^{4}$ Moreover, presently marketed anti-inflammatory drugs, namely Bendazac and Benzydamine are having indazole moiety (figure 1). Last decade (2001-2010) has witnessed an unprecedented explosion of research on the diverse biological properties of compounds having an indazole moiety.

As part of our ongoing research on indazoles ${ }^{5}$ and pyridines, ${ }^{6}$ we were interested to study $1 H$-(4-pyridyl) indazoles, because pyridine moiety alone has wide biological properties. ${ }^{7}$ Indazoles with pyridine substituted compounds also have anti-cancer properties. ${ }^{8}$ Based on this concept, we thought that by incorporating 2cyanopyridine at N1-position of indazole and further conversions may lead to superior anti-inflammatory and analgesic activity than the existing ones.

Generally, the non-steroidal inflammatory drugs are prescribed for the treatment of pain, fever, acute and chronic inflammation. There is a continuous effort to discover new and better anti-inflammatory drugs.

\footnotetext{
*For correspondence
}

\section{Experimental}

\subsection{General information}

All reagents were obtained commercially and were of the highest commercial quality and used without further purification. Solvents were freshly distilled and used. Melting points were determined in open capillaries and are uncorrected. TLC or HPLC are routinely used to check the purity of all compounds. IR spectra were recorded on a Perkin-Elmer model 2000 instrument in $\mathrm{KBr}$ phase. ${ }^{1} \mathrm{H}-\mathrm{NMR}(400 \mathrm{MHz})$ and ${ }^{13} \mathrm{C}-\mathrm{NMR}$ (100 $\mathrm{MHz}$ ) spectra were recorded in $\mathrm{CDCl}_{3}$ or DMSO using Bruker instrument and Mass spectra were recorded on a Perkin-Elmer mass spectrometer operating at $70 \mathrm{eV}$.

\subsection{General procedure for the preparation}

of 1-(2-cyanopyridin-4-yl)-1H-indazole-3-carboxylic acids $\mathbf{3 a}-\boldsymbol{b}$

To a solution of 2-cyano-4-chloropyridine $2(50 \mathrm{~g}, 0.361$ mol), methyl $1 H$-indazole-3-carboxylate 1a $(63.5 \mathrm{~g}$, $0.361 \mathrm{~mol})$ in DMSO (300 mL), CuI (6.87 g, $0.036 \mathrm{~mol})$, $L$-proline $(8.3 \mathrm{~g}, 0.0722 \mathrm{~mol})$ and cesium carbonate (235.2 g, $0.722 \mathrm{~mol}$ ) were added at RT. Reaction mass was stirred for $6-12 \mathrm{~h}$ at $75-80^{\circ} \mathrm{C}$. After completion of reaction, the reaction mass was quenched in water $(2 \mathrm{~L})$ and stirred for $30 \mathrm{~min}$. The undissolved substances were filtered through celite pad. The filtrate $\mathrm{pH}$ was adjusted to 2.0-2.5 with Conc. $\mathrm{HCl}$ to get the crude product 


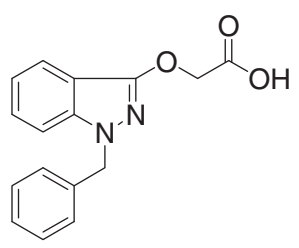

Bendazac

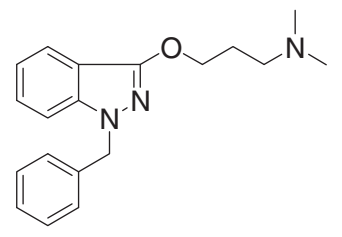

Benzydamine
Figure 1. Indazole based anti-inflammatory and analgesic drugs.

(58 g). This crude product was recrystallized from ethyl acetate to get the pure product $(55 \mathrm{~g})$.

2.2a 1-(2-cyano-pyridin-4-yl)-1H-indazole-3-carboxylic acid(3a): Yield: (57.7\%); MR: $242-245^{\circ} \mathrm{C}$; $\mathrm{IR}\left(\mathrm{KBr}, \mathrm{cm}^{-1}\right)$ : $1704(\mathrm{C}=\mathrm{O}), 2240(-\mathrm{CN}) ;{ }^{1} \mathrm{H}-\mathrm{NMR}$ (400 MHz, DMSO): $\delta 7.47(\mathrm{t}, 1 \mathrm{H}, J=7.59 \mathrm{~Hz})$, $7.63(\mathrm{t}, 1 \mathrm{H}, J=7.78 \mathrm{~Hz}), 8.10(\mathrm{~m}, 3 \mathrm{H}), 8.52(\mathrm{~d}, 1 \mathrm{H}$, $J=1.24 \mathrm{~Hz}), 8.88(\mathrm{~d}, 1 \mathrm{H}, J=5.44 \mathrm{~Hz}), 13.73$ $(\mathrm{s}, 1 \mathrm{H}) ;{ }^{13} \mathrm{C}-\mathrm{NMR}$ (DMSO, $100 \mathrm{MHz}$ ): $\delta$ 112.5, 117.4, 119.4, 120.9, 122.7, 124.9, 125.0, 129.3, 134.5, 139.7, 140.2, 146.8, 153.1, 163.0; ms: $m / z 265(264)\left(\mathrm{M}^{+}\right)$. Anal.Calcd. for $\mathrm{C}_{14} \mathrm{H}_{8} \mathrm{~N}_{4} \mathrm{O}_{2}: \mathrm{C}, 63.64 ; \mathrm{H}, 3.05, \mathrm{~N}$, 21.20, Found: C, 63.80; H, 3.30, N, 21.39.

\subsection{General procedure for the preparation of 1-(2-cyanopyridin-4-yl)-1H-indazole-3-carboxamides $4(a-g)$}

To a solution of 1-(2-cyanopyridin-4-yl)- $1 H$-indazole3-carboxylic acid 3a (10 g, $0.037 \mathrm{~mol})$, DMF (0.1 mL) in ethylene dichloride $(100 \mathrm{~mL})$, thionyl chloride $(9 \mathrm{~g}$, $0.075 \mathrm{~mol}$ ) was added at $40-45^{\circ} \mathrm{C}$ and maintained for $1 \mathrm{~h}$ at $80-85^{\circ} \mathrm{C}$. Upon completion of the reaction, the solvent was distilled off completely under atmospheric pressure to get the acid chloride. Fresh ethylene dichloride $(50 \mathrm{~mL})$ was added to the acid chloride, and cooled to $15^{\circ} \mathrm{C}$ and diethyl amine $(8 \mathrm{~g}, 0.111 \mathrm{~mol})$ was added at $15-30^{\circ} \mathrm{C}$ to $\mathrm{pH} 8.0-8.5$ and stirred for $30 \mathrm{~min}$. To the reaction mass water $(50 \mathrm{~mL})$ was added and the organic layer was separated and washed with water $(10 \mathrm{~mL})$. The organic layer was dried over anhydrous $\mathrm{Na}_{2} \mathrm{SO}_{4}$ and concentrated to get the product.

2.3a 1-(2-Cyano-pyridin-4-yl)-1H-indazole-3-carboxylic acid diethylamide(4a): Yield: (80\%);MR: 82$84^{\circ} \mathrm{C}$; IR( $\left.\mathrm{KBr}, \mathrm{cm}^{-1}\right)$ : $1630 \quad(\mathrm{C}=\mathrm{O}), 2235 \quad(-\mathrm{CN})$; ${ }^{1} \mathrm{H}-\mathrm{NMR}\left(\mathrm{CDCl}_{3}, 400 \mathrm{MHz}\right): \delta 1.33(\mathrm{~m}, 6 \mathrm{H}), 3.61$ (q, 2H), $3.70(\mathrm{q}, 2 \mathrm{H}), 7.37(\mathrm{t}, 1 \mathrm{H}, J=7.56 \mathrm{~Hz}), 7.57$ (t, $1 \mathrm{H}, J=7.72 \mathrm{~Hz}), 7.86(\mathrm{~d}, 1 \mathrm{H}, J=8.80 \mathrm{~Hz}), 7.96(\mathrm{dd}$, $\left.1 \mathrm{H}, J_{1}=1.84, J_{2}=5.46 \mathrm{~Hz}\right), 8.16(\mathrm{~s}, 1 \mathrm{H}), 8.18(\mathrm{~s}, 1 \mathrm{H})$, $8.77(\mathrm{~d}, 1 \mathrm{H}, J=5.60 \mathrm{~Hz}) ;{ }^{13} \mathrm{C}-\mathrm{NMR}(100 \mathrm{MHz}$, $\mathrm{CDCl}_{3}$ ): $\delta 12.8,14.7,40.8,43.3,110.4,116.8,116.9$, 119.4, 123.5, 124.1, 126.3, 129.2, 135.1, 138.7, 144.0, 147.4, 152.3, 161.8; ms: $m / z 320$ (319) $\left(\mathrm{M}^{+}\right)$. Anal. Calcd. for $\mathrm{C}_{18} \mathrm{H}_{17} \mathrm{~N}_{5} \mathrm{O}: \mathrm{C}, 67.70 ; \mathrm{H}, 5.37 ; \mathrm{N}, 21.93$, Found: C, 67.93; H, 5.47; N, 22.10.

\subsection{General procedure for the preparation}

of 1-(2-carbamoylpyridin-4-yl) - 1 H-indazole-3carboxamides $\mathbf{5}(\boldsymbol{a}-\mathbf{g})$

To a solution of Conc. $\mathrm{H}_{2} \mathrm{SO}_{4}(36 \mathrm{~mL}$, ) and water (0.32 $\mathrm{mL}, 0.018 \mathrm{~mol})$, sodium chloride $(0.1 \mathrm{~g}, 0.0017 \mathrm{~mol})$ was added at $10-15^{\circ} \mathrm{C}$ over a period of $30 \mathrm{~min}$, and was heated to $35^{\circ} \mathrm{C} .1$-(2-cyano-pyridin-4-yl)- $1 H$-indazole3 -carboxylic acid diethylamide $4 \mathbf{a}(6 \mathrm{~g} 0.018 \mathrm{~mol})$ was added at $35-40^{\circ} \mathrm{C}$ (by maintaining the temperature with external cooling) over a period of $30 \mathrm{~min}$. The reaction mixture was stirred for $1 \mathrm{~h}$ at $40-45^{\circ} \mathrm{C}$, and after completion of the reaction, the mass was quenched into ice-water $(250 \mathrm{~mL})$ and stirred for $30 \mathrm{~min}$ at $10-15^{\circ} \mathrm{C}$. The precipitated product is filtered and washed with chilled DM-Water $(2 \times 100 \mathrm{~mL})$ to yield the desired product.

2.4a 1-(2-carbamoyl-pyridin-4-yl)-1H-indazole-3carboxylic acid diethylamide (5a): Yield: (80\%); MR:132-134 ${ }^{\circ}$; IR( $\left.\mathrm{KBr}, \mathrm{cm}^{-1}\right): 1695(\mathrm{C}=\mathrm{O}), 1661$ $(\mathrm{C}=\mathrm{O}), 3376(-\mathrm{NH}) ;{ }^{1} \mathrm{H}-\mathrm{NMR}$ (DMSO, $\left.400 \mathrm{MHz}\right)$ : $\delta 1.14-1.25(\mathrm{~m}, 6 \mathrm{H}), 3.52(\mathrm{q}, 2 \mathrm{H}), 3.63(\mathrm{q}, 2 \mathrm{H}), 7.40$ $(\mathrm{t}, 1 \mathrm{H}, J=7.39 \mathrm{~Hz}), 7.64(\mathrm{t}, 1 \mathrm{H}, J=7.56 \mathrm{~Hz}), 7.84$ $(\mathrm{s}, 1 \mathrm{H}), 8.02(\mathrm{~d}, 1 \mathrm{H}, J=7.97 \mathrm{~Hz}), 8.08(\mathrm{~d}, 2 \mathrm{H}, J=$ $7.51 \mathrm{~Hz}), 8.25(\mathrm{~s}, 1 \mathrm{H}), 8.46(\mathrm{~s}, 1 \mathrm{H}), 8.78(\mathrm{~d}, 1 \mathrm{H}, J=$ $5.15 \mathrm{~Hz}$ ); ${ }^{13} \mathrm{C}-\mathrm{NMR}$ (DMSO, $100 \mathrm{MHz}$ ): $\delta$ 13.1, 15.0, $39.6,43.2,111.8,113.2,117.2,122.8,124.0,125.5$, 129.3, 138.8, 143.0, 147.4, 150.7, 152.6, 161.8, 165.7; ms: $m / z 338(337)\left(\mathrm{M}^{+}\right)$. Anal.Calcd. for $\mathrm{C}_{18} \mathrm{H}_{19} \mathrm{~N}_{5} \mathrm{O}_{2}$ : C, 64.08; H, 5.68; N, 20.76, Found: C, 64.29; H, 5.58; N, 20.96.

\subsection{General procedure for the preparation}

of 1-(2-methylcarbamoyl-pyridin-4-yl)-1H-indazole-3carboxaamides $\mathbf{6}(\boldsymbol{a}-\mathbf{g})$

To a solution of $4 \mathrm{a}(5 \mathrm{~g}, 0.015 \mathrm{~mol})$ in methanol $(100 \mathrm{~mL})$ was added thionyl chloride $(7.5 \mathrm{~g}, 0.063 \mathrm{~mol})$ at $40-45^{\circ} \mathrm{C}$ over a period of $10-15 \mathrm{~min}$. The reaction mixture was stirred for $1 \mathrm{~h}$ at $50-55^{\circ} \mathrm{C}$. The solvent was distilled off to get the crude product. Fresh methanol $(50 \mathrm{~mL})$ was added to the residue and mono methylamine gas was bubbled at $10-40^{\circ} \mathrm{C}$ over a period of $20 \mathrm{~min}$. The reaction mass was stirred for $30 \mathrm{~min}$ at 
$25-30^{\circ} \mathrm{C}$, distilled off the solvent to the get crude. Water $(10 \mathrm{~mL})$ and dichloromethane $(20 \mathrm{~mL})$ were added and stirred for $10 \mathrm{~min}$. The organic layer was separated and concentrated completely to get the $\mathbf{6 a}$, which was slurred in hexane $(10 \mathrm{~mL})$ and filtered to get the desired pure product.

2.5a 1-(2-methylcarbamoyl-pyridin-4-yl)-1H-indazole3-carboxylic acid diethylamide (6a): Yield (55\%); MR:132-134 ${ }^{\circ} \mathrm{C}$; IR $\left(\mathrm{KBr}, \mathrm{cm}^{-1}\right)$ : $1669 \quad(\mathrm{C}=\mathrm{O})$, $1613(\mathrm{C}=\mathrm{O})$ and $3358\left(-\mathrm{NHCH}_{3}\right) ;{ }^{1} \mathrm{H}(400 \mathrm{MHz}$,
$\left.\mathrm{CDCl}_{3}\right): \delta 1.18(\mathrm{t}, 3 \mathrm{H}, J=7.16 \mathrm{~Hz}), 1.26(\mathrm{t}, 3 \mathrm{H}$, $J=7.02 \mathrm{~Hz}), 3.02(\mathrm{~d}, 3 \mathrm{H}, J=5.01 \mathrm{~Hz}), 3.58(\mathrm{q}$, $2 \mathrm{H}), 3.71(\mathrm{q}, 2 \mathrm{H}), 7.30(\mathrm{t}, 1 \mathrm{H}, J=7.51 \mathrm{~Hz}), 7.48$ $(\mathrm{t}, 1 \mathrm{H}, J=7.70 \mathrm{~Hz}), 7.83\left(\mathrm{dd}, 1 \mathrm{H}, J_{1}=5.30, J_{2}=\right.$ $1.84 \mathrm{~Hz}), 7.91(\mathrm{~d}, 1 \mathrm{H}, J=8.48 \mathrm{~Hz}), 7.93(\mathrm{~s}, 1 \mathrm{H}), 8.17$ $(\mathrm{d}, 1 \mathrm{H}, J=8.04 \mathrm{~Hz}), 8.57(\mathrm{~d}, 1 \mathrm{H}, J=5.44 \mathrm{~Hz}), 8.62$ $(\mathrm{d}, 1 \mathrm{H}, J=1.68 \mathrm{~Hz}) ;{ }^{13} \mathrm{C}-\mathrm{NMR}\left(100 \mathrm{MHz}, \mathrm{CDCl}_{3}\right)$ : $\delta 12.8,14.6,26.0,40.8,43.4,40.8,112.8,116.9,123.3$, 123.6, 126.1, 128.6, 138.9, 142.9, 147.9, 149.4, 151.7, 162.2, 164.1. ms: $m / z 352(351)\left(\mathbf{M}^{+}\right)$. Anal.Calcd. for $\mathrm{C}_{19} \mathrm{H}_{21} \mathrm{~N}_{5} \mathrm{O}_{2}$ : C, 64.94; H, 6.02; N, 19.93, Found: C, 65.14; H, 6.20; N, 20.10 .<smiles>[R]Cc1ccc2[nH]nc(C(=O)OC)c2c1</smiles><smiles>N#Cc1cc(Cl)ccn1</smiles>

$$
\text { 1a } \mathrm{R}_{1}=\mathrm{H}
$$$$
1 \mathrm{~b} \mathrm{R}_{1}=\mathrm{Br}
$$

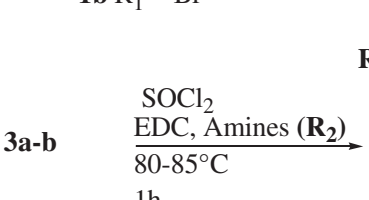<smiles>[R]C(=O)c1nn(-c2ccnc(C#N)c2)c2ccc([R])cc12</smiles>

4a-g

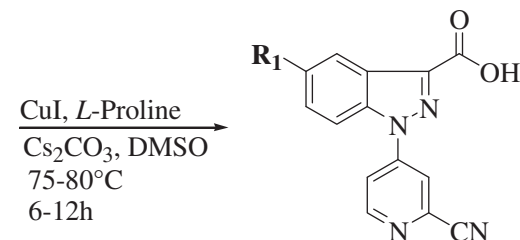

3a-b

3a $\mathrm{R}_{1}=\mathrm{H}$; MR:242-245 ${ }^{\circ} \mathrm{C}$; Yield: $57 \%$

3b $\mathrm{R}_{1}=\mathrm{Br}$; MR: $256-258^{\circ} \mathrm{C}$; Yield: $61 \%$<smiles>[R]C(=O)c1nn(-c2ccnc(C(N)=O)c2)c2ccc([R])cc12</smiles>

5a-g

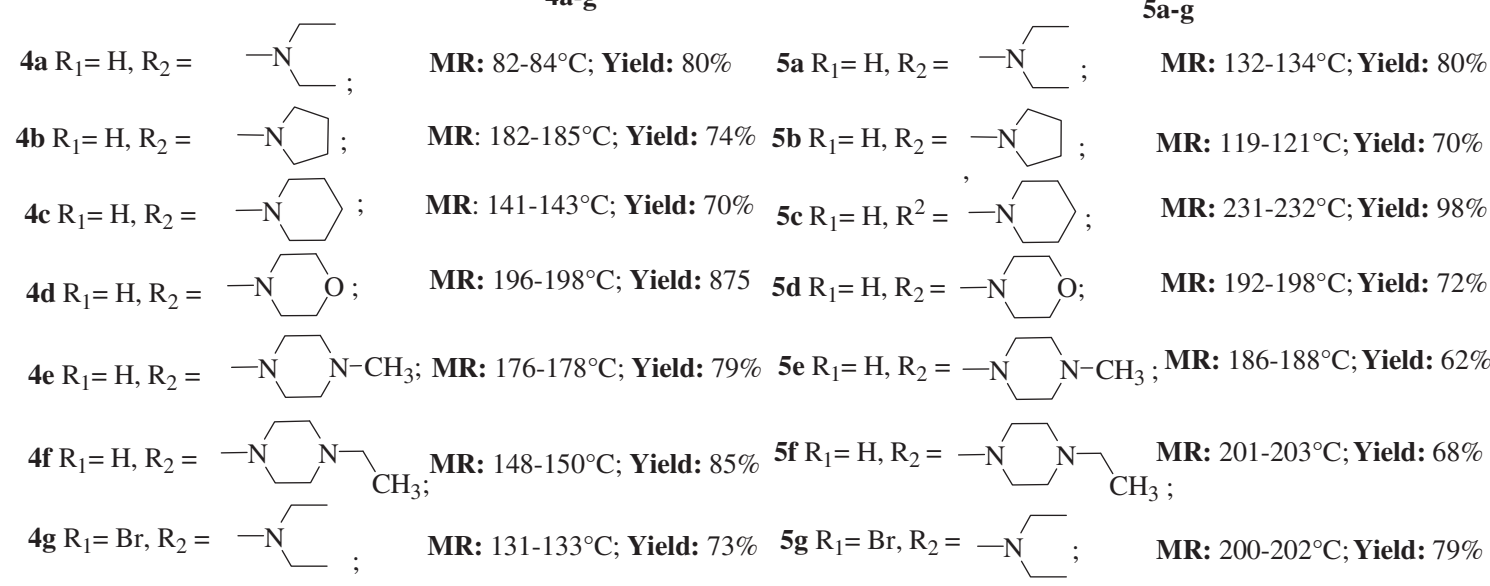<smiles>[R]C(=O)c1nn(-c2ccnc(C#N)c2)c2ccc([R])cc12</smiles>
1.SOCl ${ }_{2} /$ Methanol
$50-55^{\circ} \mathrm{C}$

2. Monomethylamine $10-40^{\circ} \mathrm{C}$

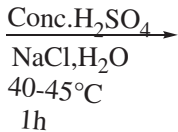
$40-45^{\circ} \mathrm{C}$

$5 \mathbf{b} \mathrm{R}_{1}=\mathrm{H}, \mathrm{R}_{2}=-\mathrm{N}$ $\left.5 c \mathrm{R}_{1}=\mathrm{H}, \mathrm{R}^{2}=-\mathrm{N}\right\rangle$

$\mathbf{5 d} \mathrm{R}_{1}=\mathrm{H}, \mathrm{R}_{2}=-\mathrm{N} \mathrm{O}$
MR: $192-198^{\circ} \mathrm{C} ;$ Yield: $72 \%$

MR: $200-202^{\circ} \mathrm{C} ;$ Yield: $79 \%$

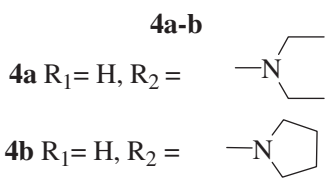

Scheme 1. Synthesis of $1 H$-pyridin-4-yl-indazole-3-carboxylic acids and derivatives. 
Table 1. Analgesic activity of novel synthetic compounds $(10 \mathrm{mg} / \mathrm{kg})$ and indomethacin $(10 \mathrm{mg} / \mathrm{kg})$.

\begin{tabular}{|c|c|c|}
\hline \multirow[b]{2}{*}{ Compound } & \multicolumn{2}{|c|}{ Mean Response (sec) } \\
\hline & $30 \mathrm{~min}$ & $60 \mathrm{~min}$ \\
\hline Control & $2.50 \pm 0.22$ & $2.66 \pm 0.21$ \\
\hline indomethacin & $\mathbf{5 . 5 0} \pm \mathbf{0 . 2 2} 2^{* *}$ & $5.66 \pm 0.21^{* *}$ \\
\hline $\mathbf{3 a}$ & $5.33 \pm 0.49^{* *}$ & $\mathbf{5 . 5 0} \pm \mathbf{0 . 3 4}{ }^{* *}$ \\
\hline $4 \mathbf{a}$ & $7.16 \pm 0.30^{* *}$ & $8.16 \pm 0.30^{* *}$ \\
\hline $4 b$ & $5.16 \pm 0.30^{* *}$ & $\mathbf{5 . 5 0} \pm \mathbf{0 . 3 4}{ }^{* *}$ \\
\hline $4 f$ & $5.16 \pm 0.30^{* *}$ & $3.16 \pm 0.30$ \\
\hline 4d & $2.83 \pm 0.30$ & $2.66 \pm 0.33$ \\
\hline $4 \mathrm{~g}$ & $3.16 \pm 0.47$ & $3.16 \pm 0.40$ \\
\hline $5 \mathbf{a}$ & $2.83 \pm 0.30$ & $2.83 \pm 0.16$ \\
\hline $5 d$ & $5.16 \pm 0.30^{* *}$ & $\mathbf{5 . 5 0} \pm \mathbf{0 . 4 2} 2^{* *}$ \\
\hline $5 e$ & $2.83 \pm 0.30$ & $2.83 \pm 0.30$ \\
\hline
\end{tabular}

Data represent mean $\pm S E(n=6)$.

Data were analyzed by using one-way ANOVA followed by Dunnett's test.

** $\mathrm{P}<0.01$ when compared with control group.

The active compounds are marked in bold letters.

\subsection{Pharmacological evaluation of newly synthesized compounds}

All compounds synthesized and reported in this article were screened for their pharmacological activities such as in-vivo analgesic and anti-inflammatory activities. These activities were carried out by measuring the physiological responses of animals to the thermal and chemical stimuli. For analgesic activity, tail immersion method $^{9}$ in rats at $10 \mathrm{mg} / \mathrm{kg}$ body weight (b.w.) was performed. The percentage increase in mean response time was calculated and compared with indomethacin. For anti-inflammatory activity, carragenan induced inflammation on hind paw edema method ${ }^{10}$ at $10 \mathrm{mg} / \mathrm{kg}$ b.w was performed. The percent of inhibition was determined for synthesized compounds as well as standard drug indomethacin.

2.6a Anti-inflammatory activity: The anti-inflammatory activity of the synthesized compounds are assessed by the carragenan induced inflammation on hind paw edema method. In all the groups vehicle, indomethacin (10 $\mathrm{mg} / \mathrm{kg}$, po) or test compounds (10 mg/kg, po) were administered $30 \mathrm{~min}$ prior to induction of edema. The edema of hind paw was induced by injection of $0.1 \mathrm{~mL}$ of $1 \%$ carragenan solution into sub-plantar region of right hind paw. The volume of paw was measured plethysmographically 30,60, 120 and $180 \mathrm{~min}$, after the injection of the irritant. Percent inhibition of the edema between control group and the test groups were calculated and compared with the group received standard drug indomethacin $(10 \mathrm{mg} / \mathrm{kg}$, po).

2.6b Analgesic activity: The analgesic activity of the synthesized compounds are assessed by the tail immersion method. The lower portion of the tail was immersed in a water bath at $55 \pm 0.5^{\circ} \mathrm{c}$. Vehicle (1\% CMC) was given to the control group; while the reference group was given indomethacin $(10 \mathrm{mg} / \mathrm{kg}$, $\mathrm{p}$ o) and the other groups were treated with newly synthesized compounds (10 mg/kg, p o). The time in seconds for the tail withdrawal from the water was taken as the reaction time, with a cut-off time of $10 \mathrm{sec}$. The reaction time for the various groups was determined at $30 \mathrm{~min}$ and $60 \mathrm{~min}$, after the drug treatment.

Table 2. Anti-inflammatory activity of novel synthetic compounds (10 mg/kg) and indomethacin $(10 \mathrm{mg} / \mathrm{kg})$.

\begin{tabular}{|c|c|c|c|c|c|c|c|c|}
\hline \multirow[b]{2}{*}{ Compound } & \multicolumn{8}{|c|}{ Paw edema } \\
\hline & $30 \mathrm{~min}$ & $\begin{array}{l}\% \text { edema } \\
\text { inhibition }\end{array}$ & $60 \mathrm{~min}$ & $\begin{array}{l}\text { \% edema } \\
\text { inhibition }\end{array}$ & $120 \mathrm{~min}$ & $\begin{array}{l}\% \text { edema } \\
\text { inhibition }\end{array}$ & $180 \mathrm{~min}$ & $\begin{array}{c}\text { \% edema } \\
\text { inhibition }\end{array}$ \\
\hline Control & $2.15 \pm 0.04$ & - & $2.33 \pm 0.06$ & - & $2.49 \pm 0.03$ & & $2.79 \pm 0.04$ & \\
\hline indomethacin & $1.28 \pm 0.04$ & $40.46^{* *}$ & $1.45 \pm 0.06$ & $37.76^{* *}$ & $1.52 \pm 0.02$ & $38.95^{* *}$ & $1.71 \pm 0.12$ & $38.70^{* *}$ \\
\hline $\mathbf{3 a}$ & $1.46 \pm 0.06$ & 32.09** & $1.36 \pm 0.06$ & $41.63^{* *}$ & $2.42 \pm 0.03$ & 2.81 & $2.61 \pm 0.05$ & 6.45 \\
\hline $4 \mathbf{a}$ & $1.95 \pm 0.05$ & 9.30 & $2.21 \pm 0.05$ & 5.15 & $2.41 \pm 0.06$ & 3.21 & $2.52 \pm 0.12$ & 9.67 \\
\hline $4 b$ & $1.30 \pm 0.03$ & $39.53^{* *}$ & $1.55 \pm 0.05$ & $33.47^{* *}$ & $1.51 \pm 0.02$ & $\mathbf{3 9 . 3 5}^{\text {** }}$ & $1.69 \pm 0.06$ & $39.42^{* *}$ \\
\hline $4 f$ & $1.32 \pm 0.03$ & $38.60^{* *}$ & $1.48 \pm 0.06$ & $36.48^{* *}$ & $1.49 \pm 0.04$ & $40.16^{* *}$ & $1.71 \pm 0.12$ & $38.70^{* *}$ \\
\hline $4 d$ & $1.98 \pm 0.04$ & 7.90 & $2.08 \pm 0.06$ & 10.72 & $2.42 \pm 0.13$ & 2.81 & $2.63 \pm 0.21$ & 5.73 \\
\hline $4 g$ & $1.95 \pm 0.06$ & 9.30 & $2.16 \pm 0.06$ & 7.29 & $1.61 \pm 0.05$ & $35.34^{* *}$ & $1.69 \pm 0.08$ & $39.42^{* *}$ \\
\hline $5 \mathbf{a}$ & $2.01 \pm 0.06$ & 6.51 & $2.13 \pm 0.06$ & 8.58 & $2.35 \pm 0.12$ & 5.62 & $2.73 \pm 0.11$ & 2.15 \\
\hline $5 d$ & $1.38 \pm 0.04$ & $35.81^{* *}$ & $1.93 \pm 0.10$ & $17.16^{* *}$ & $2.13 \pm 0.11$ & 14.45 & $2.63 \pm 0.12$ & 5.73 \\
\hline $5 e$ & $1.96 \pm 0.04$ & 8.83 & $2.15 \pm 0.09$ & 7.72 & $2.11 \pm 0.13$ & 15.26 & $2.35 \pm 0.21$ & 15.77 \\
\hline
\end{tabular}

Data represent mean $\pm \operatorname{SE}(n=6)$.

Data were analyzed using one-way ANOVA followed by Dunnett's test.

** $\mathrm{P}<0.01$ when compared with control group and the active compounds are marked in bold letters. 


\section{Results and Discussion}

\subsection{Chemistry}

We herein report a general and novel synthesis of $1 H$-pyridin-4-yl-indazole-3-carb-oxylic acid and its derivatives in good yields. Condensation of $1 \mathrm{H}$ indazole-3-carboxylicacid methyl ester 1a-b with 2cyano-4-chloropyridine 2 in the presence of $\mathrm{CuI},{ }^{11} \mathrm{~L}$ proline and cesium carbonate gave $1 \mathrm{H}$-pyridin-4-ylindazole-3-carboxylic acids $\mathbf{3 a - b}$ in moderate to good yields. Later the compounds $\mathbf{3}(\mathbf{a}-\mathbf{b})$ are converted to acid chloride and reacted with individual amines $\left(\mathbf{R}_{\mathbf{2}}\right)$ to give1-(2-cyanopyridin-4-yl)- $N, N$-diethyl- $1 H$-indazole-3-carbox-amides $\mathbf{4}(\mathbf{a}-\mathbf{g})$ with good yields and $\mathbf{4 g}$ was confirmed by single crystal structure analysis ${ }^{12}$ (CCDC 947891). Later, hydrolysis of $\mathbf{4}(\mathbf{a}-\mathbf{g})$ under acidic conditions gave 1-(2-carbam-oylpyridin-4-yl)$N, N$-diethyl- $1 H$-indazole-3-carboxamides $\mathbf{5}(\mathbf{a}-\mathbf{g})$, and also $\mathbf{4}(\mathbf{a}-\mathbf{b})$ were converted into picolinates in the presence of methanol and thionyl chloride and then reacted with mono methylaminein methanol to give corresponding 1-(2-methylcarbamoyl-pyridi-n-4-yl)- $1 H$ indazole-3-carboxylic acid amides (6a-b). The total reaction strategy is depicted in scheme 1 .

\subsection{Structure activity relationship $(S A R)$}

The analgesic activity of the novel compounds were analyzed by the tail immersion method. ${ }^{9}$ As part of SAR studies, we initially screened the analgesic activity on compound 3a. Oral treatment with compound $\mathbf{3 a}$ with $-\mathbf{C N}$ substitution at $2^{\text {nd }}$ position of pyridine moiety as well as $-\mathbf{C O O H}$ substitution at $C-3$ position of indazole moiety showed significant analgesic activity and this effect was similar to that of indomethacin. We prepared a series of $C-3 \& C-5$ derivatives based on this result.

Converting - $\mathbf{C O O H}$ group into carboxamides with pyrrolidine (4b) and $N$-ethyl piperazine (4f) showed equipotent activity. Whereas, the compound $\mathbf{4 d}$ morpholine amide showed poor activity. Furthermore, the compound 4a with diethyl amide showed a remarkable increase in potency. The compound $\mathbf{4 g}$ with bromo substitution at $C-5$ position showed moderate activity.

Based on the above results, we focused on modification at $2^{\text {nd }}$ position of pyridine ring. Replacement of $\mathbf{- C N}$ substitution by $-\mathbf{C O N H} \mathbf{C H}_{\mathbf{2}}$ (5a) showed moderate activity and similar effect is observed with compound 5e. The compound $5 \mathbf{d}$ showed equipotent activity when compared to reference standard indomethacin (table 1).
As part of other bio studies, we were interested to check the anti-inflammatory activity of all these compounds. The compound 3a with $-\mathbf{C N}$ substitution at $2^{\text {nd }}$ position of pyridine ring and - $\mathrm{COOH}$ substitution at $C-3$ position showed significant effect at 30 and 60 min but failed to show similar effect at 120 and 180 min. Furthermore, the compound $\mathbf{4 b}$ with pyrrolidine substitution and compound $\mathbf{4 f}$ with $N$-ethyl piperazine showed a remarkable activity in all intervals and this effect is similar to that of indomethacin. Treatment with compound $\mathbf{4 g}$ showed equipotent activity at 120 and $180 \mathrm{~min}$ but failed to show similar effect at 30 and 60 min. Similarly the compound 5d showed moderate activity at 30 and $60 \mathrm{~min}$ but failed to show similar effect at 120 and $180 \mathrm{~min}$ whereas the compound 5e with $N$-methyl piperazine substitution showed poor activity (table 2 ).

\section{Conclusion}

We have synthesized $1 H$-pyridine-4-yl-3,5-disubstituted indazoles and found $\mathbf{4 b}, \mathbf{4 f}$ and $\mathbf{4 g}$ exhibited potent anti-inflammatory activity and compounds $\mathbf{3 a}, \mathbf{4 a}, \mathbf{4 b}$ and $\mathbf{5 d}$ exhibited potent analgesic activity as that of standard drug indomethacin.

\section{Supplementary Information}

Copies of NMR spectra for compounds 3a-b, 4a-g, 5a-g and $\mathbf{6} \mathbf{a}-\mathbf{b}$ are available at www.ias.ac.in/chemsci.

\section{Acknowledgments}

The authors are grateful to management of Suven Life Sciences for allowing them to publish these results of the preliminary laboratory work.

\section{References}

1. (a) Zhao Q, Du J, Gu H, Teng X, Zhang Q, Qin H and Liu N 2007 Pancreas 34 242; (b) Raffa D, Maggio B, Cascioferro S, Raimondi M V, Schillaci D, Gallo G, Daidone G, Plescia S, Meneghetti F, Bombieri G, Christiana A D, Pipitone R M, Grimaudo S and Tolomeo M 2009 Eur. J. Med. Chem. 44165

2. (a) Iwakubo M, Takami A, Okada Y, Kawata T, Tagami Y, Ohashi H, Sato M, Sugiyama T, Fukushima K and Iijima H 2007 Bioorg. Med. Chem. 15 350; (b) Meyers M J, Arhancet G B, Heckerman S L, Chen X, Long S A, Mahoney M W, Rico J R, Garland D J, Blinn J R, Collins J T, Yang S, Haung H, McGee K F, Wendling J M, Dietz J D, Payne M A, Homer B L, Heron M I, Reitz D B and Hu X 2010 J. Med. Chem. 535979 
3. (a) Rodgers J D, Johnson B L, Wang H, EricksonViitanen S, Klabe R M, Bacheler L, Cordova B C and Chang C H 1998 Bioorg. Med. Chem. Lett. 8 715; (b) Shi J J, Ji F H, He P L, Yang Y X, Tang W, Zuo J P and Li Y C 2013 Chem. Med. Chem. 8722

4. Huang L J, Shih M L, Chen H S, Pan S L, Teng C M, Lee F Y and Kuo S C 2006 Bioorg. Med. Chem. 14 528

5. (a) Veera Reddy A, Surendra Reddy G and Dubey P K 2014 J. Heterocycl. Chem. 51 1311; (b) Veera Reddy A, Surendra Reddy G and Dubey P K 2013 Synth. Commun. 43 2236; (c) Surendra Reddy G, Arunasree K M, Dubey P K and Veera Reddy A 2014 J. Chem. Sci. 41055

6. Veera Reddy A, Surendra Reddy G and Dubey P K 2011 J. Heterocycl. Chem. 48961

7. (a) Jones G 1996 In Comprehensive Heterocyclic Chemistry II A R Katritzky, C W Rees and E F V Scriven (Eds.) (Oxford: Pergamon) p. 167; (b) Balasubrahmanian
M and Keay J G 1996 In Comprehensive Heterocyclic Chemistry IIA R Katritzky, C W Rees and E F V Scriven (Eds.) (Oxford: Pergamon) p. 245; (c) Kumar $\mathrm{R}$ and Chandra R 2001 Adv. Heterocycl. Chem. 78 269; (d) Gavin D H 2004 Tetrahedron. 606043

8. Woods K W, Fischer J P, Claiborne A, Li T, Thomas S A, Zhu G D, Diebold R B, Liu X, Shi Y, Klinghofer V, Han E K, Guan R, Magnone S R, Johnson E F, Bouska J J, Olson A M, Jong R D, Oltersdorf T, Luo Y, Rosenberg S H, Girandaa V L and Li Q 2006 Bioorg. Med. Chem. 146832

9. D‘Amour F E and Smith D L 1941 J. Pharmacol. Exp. Ther. 7274

10. Winter C A, Risley E A and Nuss G W 1962 Proc. Soc. Exp. Biol. Med. 111544

11. Antilla J C, Baskin J M, Barder T E and Buchwald S L 2004 J. Org. Chem. 695578

12. Anuradha G, Vasuki G, Surendra Reddy G, Veera Reddy A and Dubey P K 2014 Cryst. Rep. 4527 